\title{
HISTOLOGICAL STUDY OF A CORRECTIVE INFLUENCE OF A COMPOUND POTASSIUM 2-((4-AMINO-5-(MORPHOLINOMETHYL)- 4H-1,2,4-TRIAZOL-3-YL)THIO)ACETATE (PKR-173) ON THE STATE OF CHICKEN'S LIVER UNDER INFECTION BY PSEUDOMONAS AERUGINOSA
}

PSEUDOMONAS AERUGINOSA ILE ENFEKTE EDILMISS CIVCIVLERIN KARACİĞERINE POTASYUM 2-((4-AMINO-5-(MORFOLINOMETIL)-4H-1,2,4-TRİAZOL-3IL)TIYO)ASETAT (PKR-173) BILLEŞIĞİNIN DÜZELTICI ETKISINIIN HISTOLOJIK OLARAK ARAŞTIRILMASI

\section{Yevgenia VASHCHYK ${ }^{1}$, Roman SHCHERBYNA ${ }^{1, *}$, Volodymyr PARCHENKO ${ }^{2}$, Inna BUSHUEVA $^{2}$, Bogdan GUTYJ ${ }^{3}$, Hanna FOTINA ${ }^{1}$, Tatiana FOTINA ${ }^{1}$, Yuriy STRONSKYI ${ }^{3}$}

${ }^{1}$ Sumy National Agrarian University, Faculty of Veterinary Medicine, Department of Veterinary Sanitary Examination, Microbiology, and Zoohygiene Safety and Quality of Animal Products, Sumy, Ukraine

${ }^{2}$ Zaporizhzhya State Medical University, Faculty of Pharmacy, Department of Natural Sciences for Foreign Students and Toxicological Chemistry, Zaporizhzhya, Ukraine

${ }^{3}$ Stepan Gzhytskyi National University of Veterinary Medicine and Biotechnologies, Faculty of Veterinary Medicine, Department of Pharmacology and Toxicology, Lviv, Ukraine

\section{ABSTRACT}

Objective: The aim of the research is the histological study of the corrective effect of the compound potassium 2((4-amino-5-(morpholinomethyl)-4H-1,2,4-triazol-3yl)thio)acetate (PKR-173) with different antibiotics on the state of chicken's liver under infection by Pseudomonas aeruginosa.

Material and Method: The histological study was carried out on the levers of intact chickens (intact control); chickens that were infected by the strain of Pseudomonas aeruginosa (controlled pathology); chickens that had (before being infected by Pseudomonas aeruginosa) preventive input of the compound PKR-173 with

\footnotetext{
* Corresponding Author / Sorumlu Yazar: Roman Shcherbyna e-mail/e-posta: rscherbyna@gmail.com
} 
the classic antibiotic Enrofloxacin or with Saroflox (undergoing research); or were input Thiotriazolin with the classic antibiotic Enrofloxacin.

Result and Discussion: As a result, it is stated, that preventive input of the compound PKR-173 with reseachable antibiotic Saroflox, as well as with classic antibiotic Enrofloxacin and Thiotriazolin with antibiotic Enrofloxacin, to chickens infected with pseudomonas aeruginosa, prevents from chickens' livers developing stereotypical morphological changes characteristic of nonspecific reactive hepatitis. Analysis of quantitative characteristics of pathological process that developed in chicken's liver infected with pseudomonas aeruginosa, and the corrective influence of researched methods showed that the compound PKR-173 with antibiotic Saroflox believably lowers displays of all signs of pathology compared to the controlled pathology.

Keywords: 1,2,4-triazole, hepatitis, hepatoprotective effect, infection of pseudomonas, saroflox

\section{$\ddot{\mathbf{O Z Z}}$}

Amaç: Araştırmanın amacı, potasyum 2-((4-amino-5-(morfolinometil)-4H-1,2,4-triazol-3-il)tiyo)asetat (PKR-173) bileşiğinin farkl antibiyotikler ile birlikte Pseudomonas aeruginosa ile enfekte edilmiş civcivlerin karaciğerine düzeltici etkisinin histolojik olarak incelenmesidir.

Gereç ve Yöntem: Histolojik araştırma, sağlam civcivler (kontrol), Pseudomonas aeruginosa ile enfekte edilmiş civcivler (kontrol edilen patoloji), (Pseudomonas aeruginosa ile enfekte edilmeden önce) PKR-173 bileşiği ile Enrofloxacin veya Saroflox gibi klasik antibiyotik yada tiotiazolin ile Enrofloxacin antibiyotiği verilen civcivlerin karaciğeri üzerinde yapılmıştır.

Sonuç ve Tartışma: Araştırmaların sonucunda; araştırlan antibiyotik olan Saroflox ile PKR-173 bileşiğinin ve önleyici bir şekilde Pseudomonas aeruginosa ile enfekte edilmiş civcivlere uygulanan Enrofloxacin ve Thiotriazolin- Enrofloxacin gibi klasik antibiyotiklein, nonspesifik reaktif hepatite özgü olan karaciğerdeki standart morfolojik değişiklikleri önlediği tespit edilmiştir. Pseudomonas aeruginosa ile enfekte edilmiş civcivlerin karaciğerinde gelişen patolojik sürecin kantitatif özelliklerinin analizi ve düzeltici etkisi araştırllan metot, Saroflox antibiyotiği ile PKR-173 bileşiğinin, kontroldeki patolojiye klyasla patolojinin bütün belirtilerini azalttı̆̆ını göstermiştir.

Anahtar Kelimeler: 1,2,4-triazol, hepatit, hepatoprotektif etki, pseudomonas enfeksiyonu, saroflox

\section{INTRODUCTION}

Hepatoprotective remedies are still in high demand [1]. They raise liver's resistance to the effects of toxic agents and normalize its metabolism in conditions of intensive detoxication function. The mechanisms of damage to the liver may be different, but among the many, used for liver treatment, a doctor has to choose the optimal one both from the perspective of etiology and pathogenesis, as well as clinical presentation of a disease. Unfortunately, the variety of the existent domestic hepatoprotective remedies isn't big.

Safety, tolerance to the drug, possibility of continuous intake, economical reasoning are the deciding factors in favour of choosing certain hepatoprotective remedies. The widening of hepatoprotectors' variety, caused by implementing new discoveries in biochemistry, molecular biology and nanotechnology, is on agenda for modern scientists [2, 3].

Many 1,3,4-oxadiazole, 1,2,4-triazole and 1,3,4-thiadiazole derivatives are of great interest and are associated with a broad spectrum of pharmacological activities [4-9]. Ribavirin, fluconazole and cefazolin are antiviral, antifungal and antibacterial drugs that contain units of 1,2,4-triazole and 1,3,4thiadiazole. Furthermore, the 1,3,4-oxadiazole ring system has been found in the skeleton of fungicidal and bactericidal, analgesic, antipyretic, antiphlogestic, anticompulsive, paralytic hypnotic and sedative 
agents [10-12] in addition to antiviral, antitumour [13] and tyrosinase inhibiting agents [14]. Moreover, various substituted 1,2,4-triazolo[3,4-b]-1,3,4-thiadiazoles and their dihydro analogues have been shown to possess antimicrobial, antibacterial [15], anti-inflammatory [16], antifungal, CNS-depressant and antiviral [17] activities.

The data on studying hepatoprotective properties of the above-mentioned compounds under hepatitis, caused by the toxic influence of chemical substances, is present in scientific literature $[18,19]$. The aim of our research was to study hepatoprotective properties of the compound PKR-173 under conditions of bacterial toxins on chickens' organisms. It is known that upon experimental infection by Pseudomonas aeruginosa chickens develop conditional characteristic of toxic liver damage [20,21]. Thus histological study of the corrective effect of the compound "potassium 2((4-amino-5(morpholinomethyl)-4H-1,2,4-triazol-3yl) thio) acetate" (PKR-173) with different antibiotics on the state of chicken's liver under infection by Pseudomonas aeruginosa we deem appropriate [22].

The aim of the research is the histological study of the corrective effect of the compound "potassium 2((4-amino-5-(morpholinomethyl)-4H-1,2,4-triazol-3yl) thio) acetate" (PKR-173) with different antibiotics on the state of chicken's liver under infection by Pseudomonas aeruginosa.

\section{MATERIAL AND METHOD}

As an object of research potassium 2-((4-amino-5-(morpholinomethyl)-4H-1,2,4-triazole-yl3)thio)acetate (PKR-173) was used [23].

Experimental studies were held under conditions of the department of natural sciences for foreign students and toxicological chemistry of Zaporizhzhya State Medical University and departments of veterinary sanitary expertise, microbiology, veterinary public health and safety and quality of products of animal breeding of Sumy National Agrarian University. Histological research was conducted at central research laboratory of the National University of Pharmacy.

The study was conducted on chickens aged 7-18 days. The histological study was carried out on the levers of intact chickens (intact control); chickens that were infected by the strain clinical isolate of P. aeruginosa (controlled pathology) [24]; chickens that had (before being infected by P. aeruginosa) preventive input of the compound PKR-173 with the classic antibiotic Enrofloxacin or with Saroflox (undergoing research); or were input Thiotriazolin with the classic antibiotic Enrofloxacin. The strain $P$. aeruginosa ATCC 27853 were used as a control reference strain.

$P$. aeruginosa culture was intraperitoneally input in chickens on the 4th day of the experiment with a solution of $300.000 \mathrm{CFU} / \mathrm{ml}$ (by McFarland [25]), with the dosage of $0.2 \mathrm{ml}$ (LD50 by the Kerber method in the modification of Ashmarin) [26]. The compound PKR-173 (in powder form) and Thiotriazolin (in powder form) was input per os during the 3 days before the infection and 5 days after, 
with a dosage of $150 \mathrm{mg} / \mathrm{kg}$ and $50 \mathrm{mg} / \mathrm{kg}$ respectively [27, 28]. Antibiotics were input during the 5 days after the infection.

The selection of liver samples of each chickens' group of the experiment was carried out on the 6th day after the infection. The material was fixed in a $10 \%$ solution of formaldehyde, and was dehydrated in alcohols of increasing strength, and embedded in paraffin wax. The paraffin blocks' slices of 4-5 $\mu$ min width were produced on sled microtome "MC 2" and painted for observation microscopy with hematoxylin (Mayer's hemalum solution) and eosin [29]. Microscopic study of the microscope slide were conducted on Granum microscope, and the photography of the microscopic images was done with digital camera Granum DCM 310. The photographs were edited on Pentium computer with 2,4GHz frequency with an application Toup View.

For the conveniency of comparison and greater objectification of the results on hematoxylin and eosin painted microscope slides, the quntitative (graded) assessment of degrees of liver damage of chickens of different study groups was done. The distinctiveness of hepatocytes' dystrophy, presence and distribution of areas of breached beam pattern, cell necrosis, cell infiltration of blood vessels were assessed. It was based on semiquantitative visual assessment of output of histochemical reactions, by Sokolovsky method [30]. Each type of damage was assessed separately.

The dispersion analysis (Kruskal-Wallis criteria) was conducted for statistical results, and MannWhitney criteria with probability $\leq 0,05$ - for comparing data samples [31-35]. For statistical processing the Statistuca 6.0 was used.

\section{RESULT AND DISCUSSION}

The results of bright-field microscopy analysis of intact chickens show that histostructure of their liver corresponds to the healthy organ and is inherent to the age of [30,31]. The lobules structure is not shown. The inter-lobules connective tissue is underdeveloped. The borders of lobules were indentified by the portal triad (passing zone for branches of hepatic artery, portal vein and common bile duct). The passing zones themselves are quite narrow. The parenchymal lobules consist of hepatocyte plates, which consist of a few polygonal hepatocytes each, with rounded and well-bordered centre-placed nuclei (one for a cell), in which nucleoli and chromatin macromolecules are well visible. The hepatocyte cytoplasm is well coloured, doesn't show inserts visible on bright-field microscopic level. Radial direction of the liver plates is the most prominent close to central veins, at a distance from them - the plates are more round. Between the liver plates are sinusoidal hemocapillaries that show a very limited amount of lymphoid cells and nuclei erythrocytes. Central and inter-lobules veins and triad vessels are not expanded, as a rule, and not filled with blood, Kupffer cells have no distinctive features (fig. 1, fig. 2). In some chickens close to some inter-lobules veins the lymphocytic clusters of various sizes were discovered. 


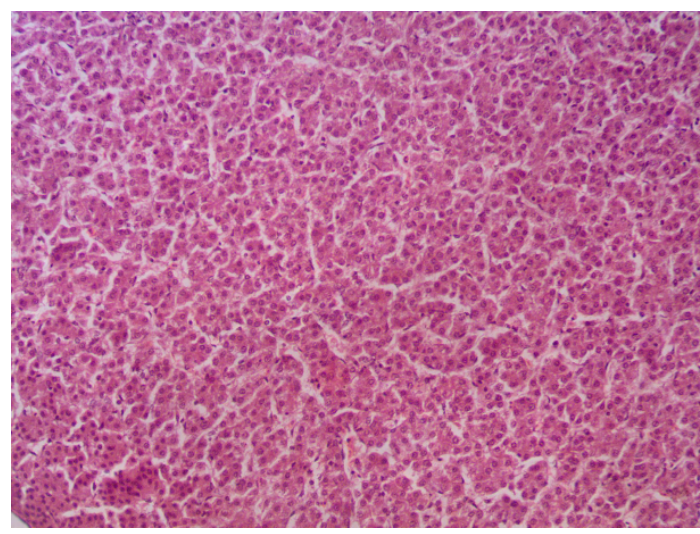

Figure 1. Area of an intact chicken's liver. The liver plates look clear, hepatocytes have evenly coloured cytoplasm, normal nuclei, sinusoidal hemocapillaries are moderately expanded.

Hematoxylin-eosin. x200

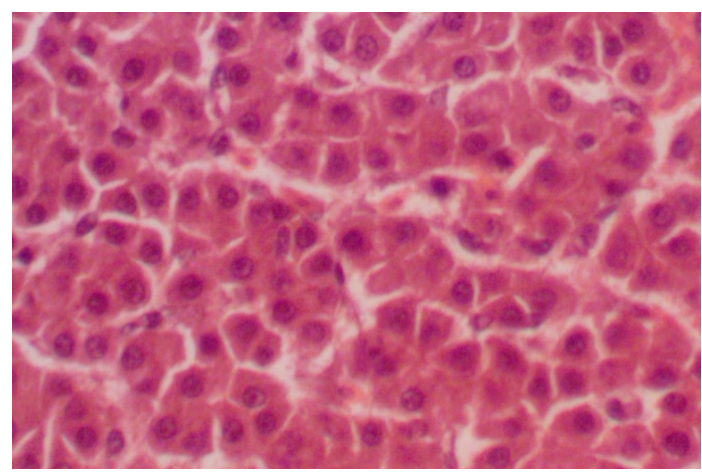

Figure 2. A fragment of fig. 1. Hematoxylin-eosin. x400

After infecting the chickens with $P$. aeruginosa their liver showed nonspecific morphological changes that occur under different diseases of liver and other organs and systems, and can be also caused by overall toxic influence endotoxins of a given microorganism. Chickens showed disorganisation of a outline of liver plates, vacuole (fatty and mainly hydropic) distrophy of hepatocytes, small focuses of necrosis, inflammatory cell infiltration. As a rule, prevalence of deviation zones of plates outline, distinctiveness of fatty and hydropic hepatocyte dystrophy, presence and numerosity focuses of parenchyma necrosis varied among chickens of the group. Moreover, different combinations of these pathological signs were observed. That way the structure disorganisation was combined more often with a dystrophy, and necrosis - with cell infiltration. Vecuoles had pepperish nature. Hydropic dystrophy is observed at certain places as well (fig. 3, fig. 4). 


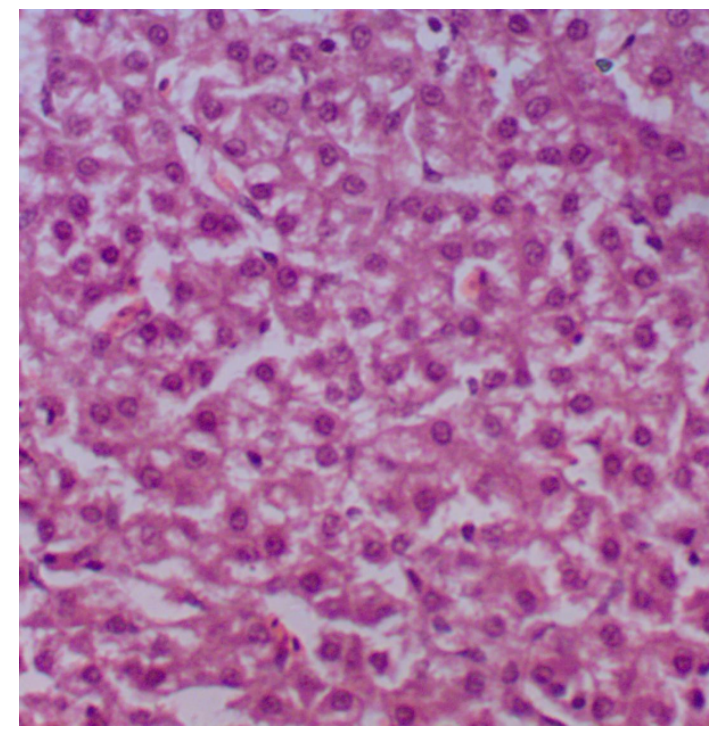

Figure 3. Area of a chicken's liver infected with P. aeruginosa. Hepatocyte dystrophy, deviations in plates outline. Hematoxylin-eosin. $\mathrm{x} 400$

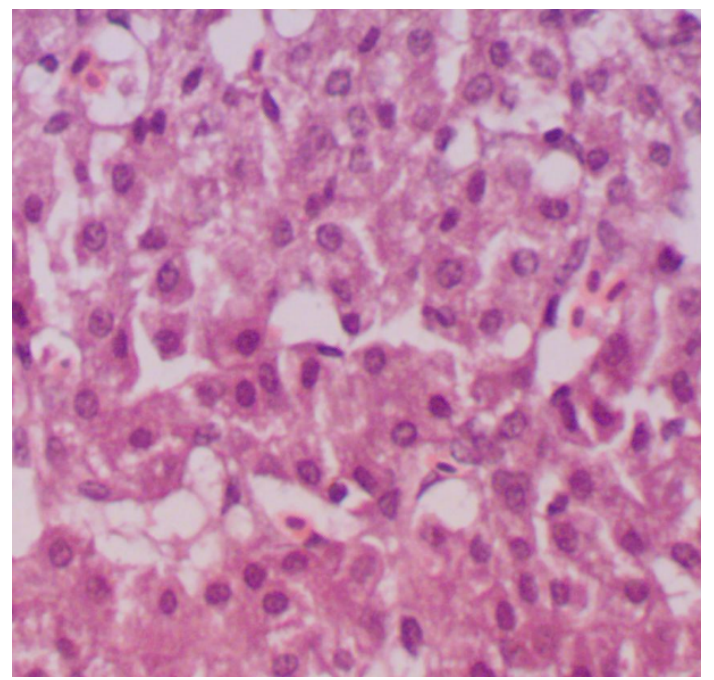

Figure 4. Area of a chicken's liver infected with P. aeruginosa. Hydropic hepatocyte dystrophy. Hematoxylin-eosin. x400

In zones of liver plates' disorganisation the hepatocytes were swollen, varied in size, had blurred boundaries, various-sized nuclei with poorly visible colouring or were in a state of karyolisys; visible focals of cell lysis (fig. 5). 


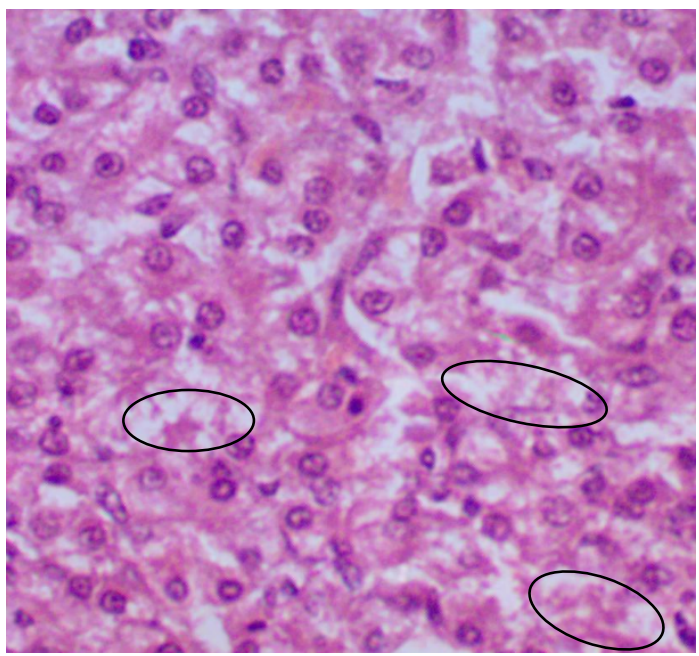

Figure 5. Area of a chicken's liver infected with P. aeruginosa. Lysis of part of hepatocytes (ellipses), different states of cell nuclei. Hematoxylin-eosin. x400

Sometimes apoptotic bodies (Councilman bodies) were visible as round eosinophile formations with pyknotic nuclei or without, the appearance of hepatocytes in a state of cell division (fig. 6). Moreover, a vacuolesation of bile ducts' endothelium in some triads, minor biliary hyperplasia was observed (fig. 7).

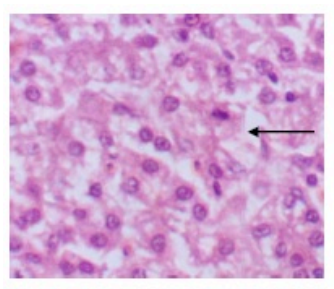

a

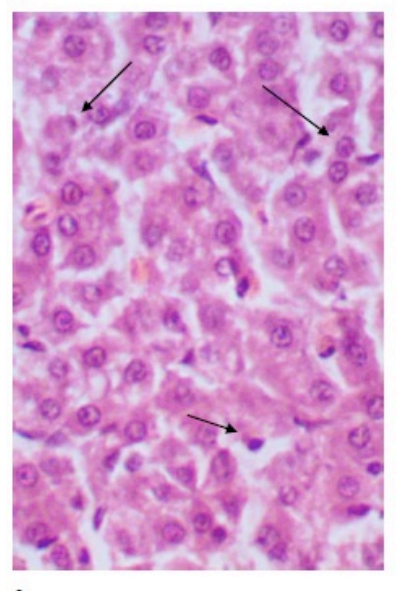

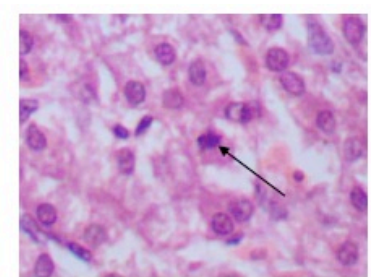

b

Figure 6. Area of a chicken's liver infected with $P$. aeruginosa. a-b - mitosis in hepatocytes; $\mathrm{c}-$ Councilman bodies (arrows). Hematoxylin-eosin. x400. 


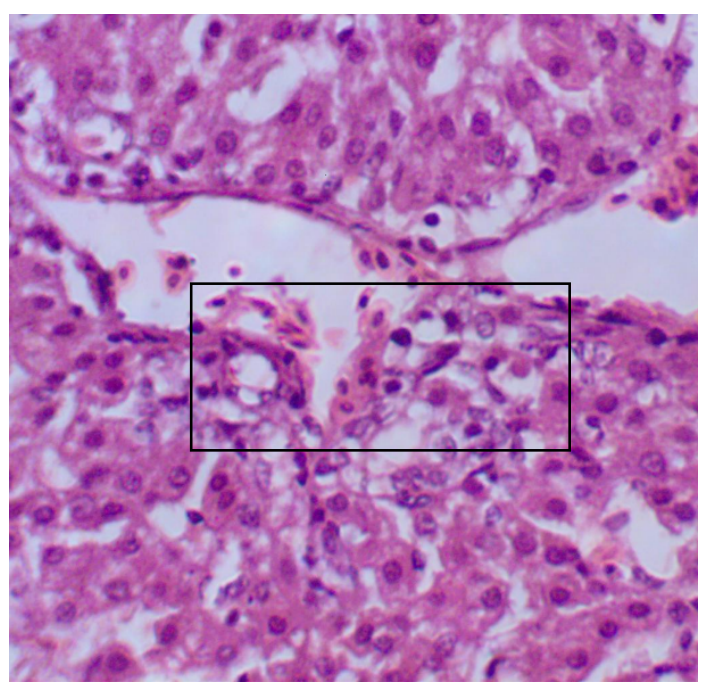

Figure 7. Area of a chicken's liver infected with $P$. aeruginosa. Vacuolesation of endothelium, minor biliary hyperplasia in a triad. Hematoxylin-eosin. x400.

Hepatocyte necrosis (colliquative, monocellular) was of minor focal necrosis character. Focuses of necrosis were localized in different areas of lobules, often had quite clear borders, and usually abundantly infiltrated by limphoid cells' plates. Sometimes the infiltrated cells "spread out" between liver plates. In some necrosis focuses, among infiltrated cells, "immured" groups of hepatocytes were visible (fig. 8).

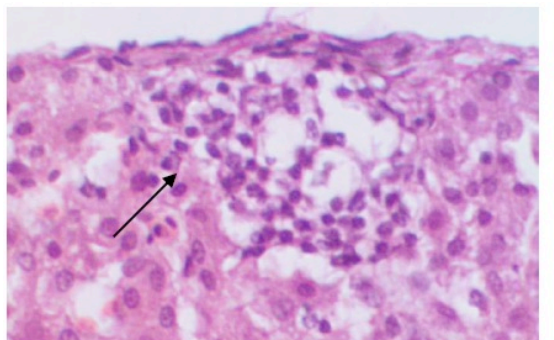

a

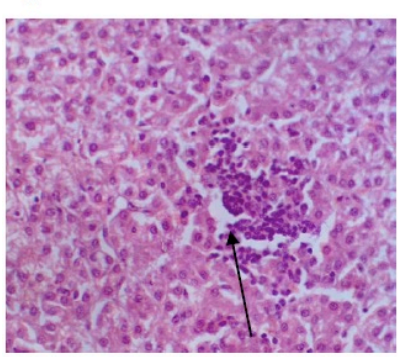

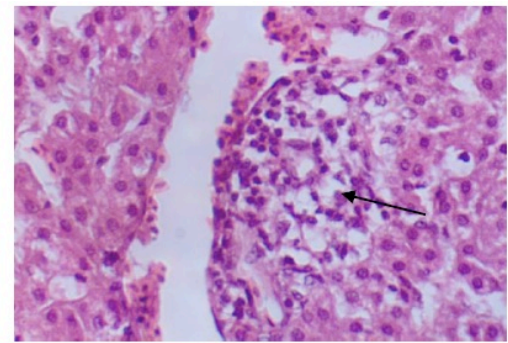

$\mathrm{b}$

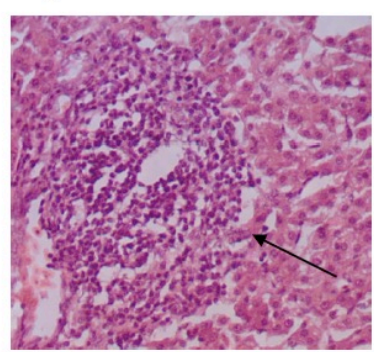

Figure 8. Area of a chicken's liver infected with P. aeruginosa. Minor focals of hepatocytes necrosis of different locations ( $\mathrm{a}$ - subcapsular, $\mathrm{b}$ - near the inter-lobules vein, $\mathrm{c}$ - in parenchyma of a lobule, $\mathrm{d}$ - periportal), penetration of infiltrated cells between liver plates (c), "immured" hepatocytes among infiltrated cells (d). Hematoxylin-eosin. a,b,d - x250, c- x400 
In some triads perivenularly, close to some central veins, moderate/minor inflammatory polymorphic cell infiltration is observed. Among the infiltrated cells lymphocytes, some neutrophile white blood cells, macrophages were visible (fig. 9).

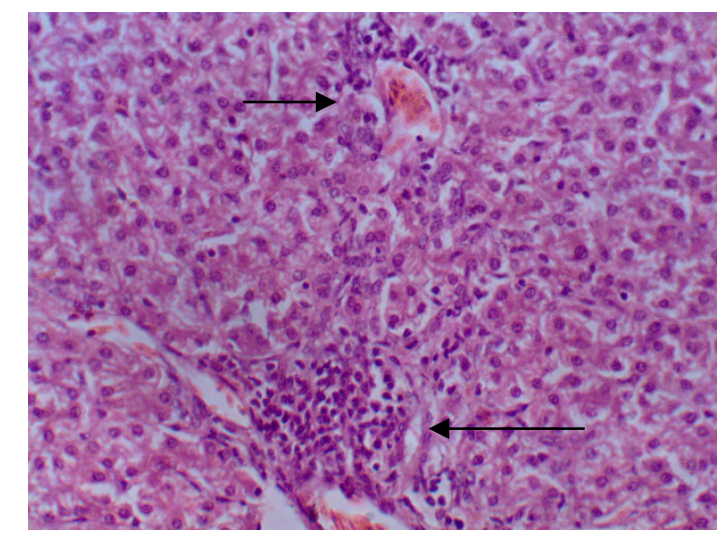

a

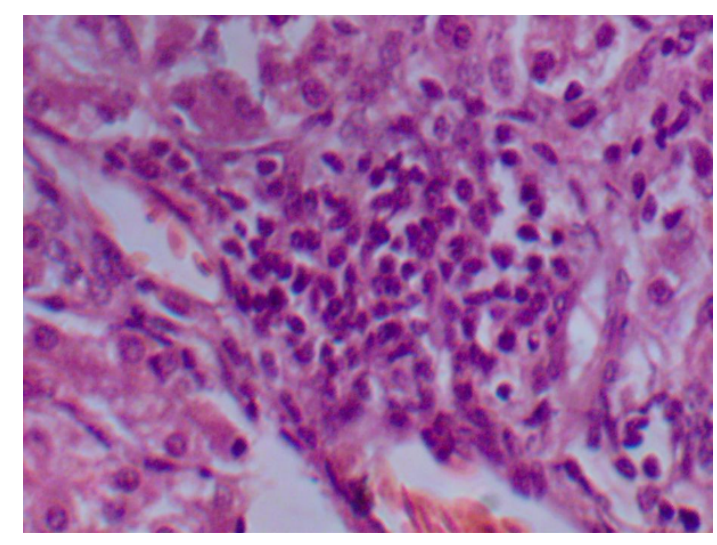

b

Figure 9. Area of a chicken's liver infected with P. aeruginosa. Moderate/minor inflamed cell infiltration close to central vein and triad vein ( $\mathrm{a}, \mathrm{x} 200$ ), lymphocytes, neutrophile white blood cells and macrophages in inflamed infiltration $(b, x 400)$. Hematoxylin-eosin.

Suggested microscope picture, by morphological features, corresponds to moderately shown nonspecific reactive hepatitis (fig. 8).

After getting the compound PKR-173 with researchable antibiotic Saroflox, 80\% of chickens, infected with $P$. aeruginosa, almost fully restored typical outline of liver plates and normal morphology of hepatocytes. In some hepatocytes nuclei were visually hypertrophied, the contents of two-nuclei cells were visually increased (non-direct evidence of regenation). Fatty and hydropic dystrophy is absent in $40 \%$ of birds, or distinctly lowered - in $60 \%$ (fig. 10). In $20 \%$ of chickens minor inflammatory infiltration of veins in some triads was observed, as well as single minor focuses of necrosis (fig. 11, fig. 12). Microcircular blood vessels were moderately blood-filled in all chickens.

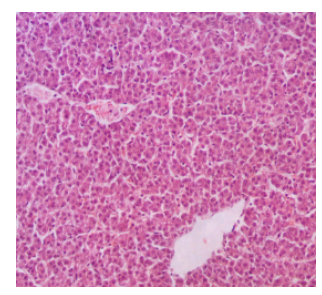

Figure 10. Area of a chicken infected with P. aeruginosa and input the compound PKR-173 with the antibiotic Saroflox. Full recovery of normal histostructure, absence of hepatocyte dystrophy, normal state of microcircular blood vessel. Hematoxylin-eosin. x250 


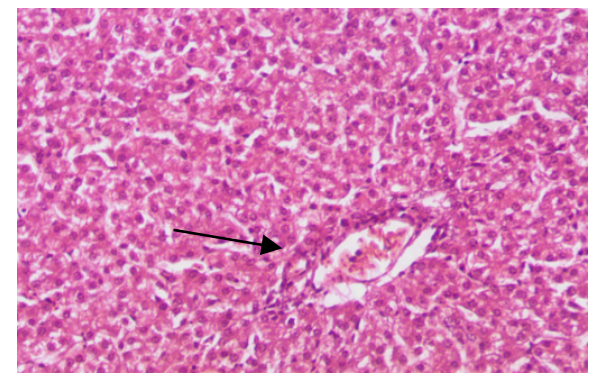

Figure 11. Area of a chicken infected with $P$. aeruginosa and input the compound PKR-173 with the antibiotic Saroflox. Minor inflammatory cell infiltration in triad zone. The distinctiveness of the dystrophy is lowered. Hematoxylin-eosin. x250

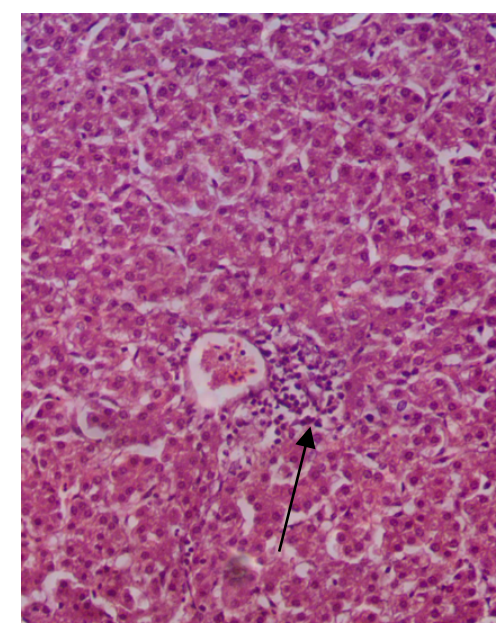

Figure 12. Area of a chicken infected with $P$. aeruginosa and input the compound PKR-173 with the antibiotic Saroflox. Small focus of necrosis infiltrated by round cell elements next to the central vein of lobules. Hematoxylin-eosin. x250

After preventive input of compound PKR-173 with a classic antibiotic Enrofloxacin in $80 \%$ of chickens the plate structure of liver parenchyma is restored, hepatocyte dystrophy is absent (fig. 13).

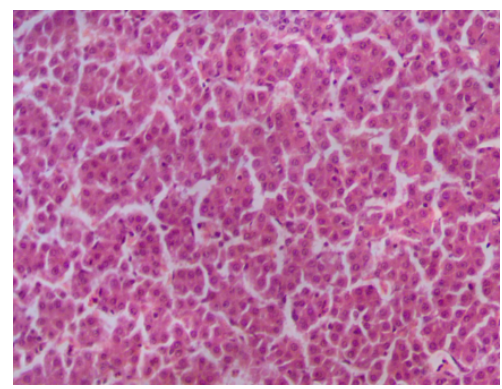

Figure 13. Area of a chicken infected with $P$. aeruginosa and input the compound PKR-173 with the antibiotic Enrofloxacin. Absence of breaches in liver plates outline, as well as hepatocyte dystrophy. 
Single very small focuses of necrosis are present in $20 \%$ of chickens (fig. 14). At the same time, almost all chickens kept different distinctive inflammatory round cells infiltration close to central veins and vessels in many triads. Infiltrators consisted of lymphocytes, some neurophile white blood cells, macrophages (fig. 15a). In one case the focal expansion and full-bloodness of sinusoidal hemocapillaries, minor hemorrhages with destruction of parenchyma (fig. 15b).

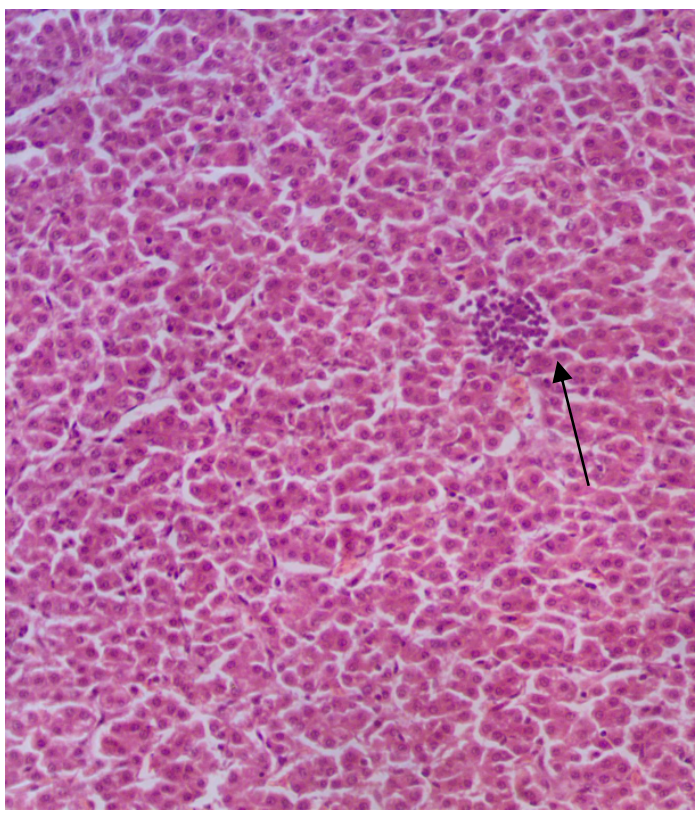

Figure 14. Area of a chicken infected with $P$. aeruginosa and input the compound PKR-173 with the antibiotic Enrofloxacin. Single small focus of necrosis in lobules parenchyma. Hematoxylin-eosin.

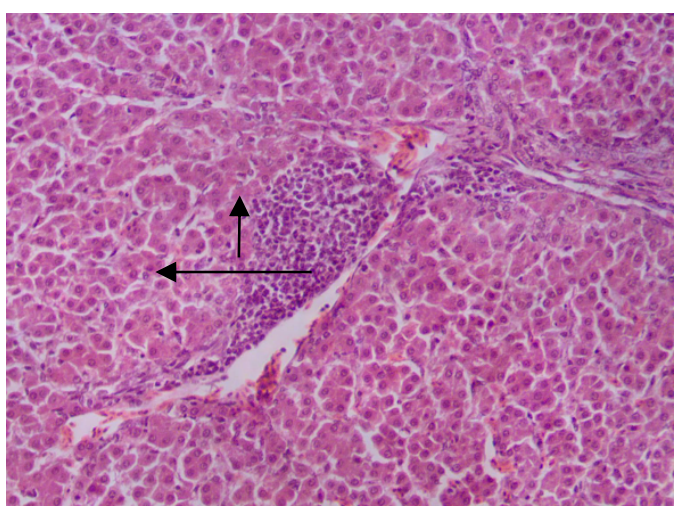

a

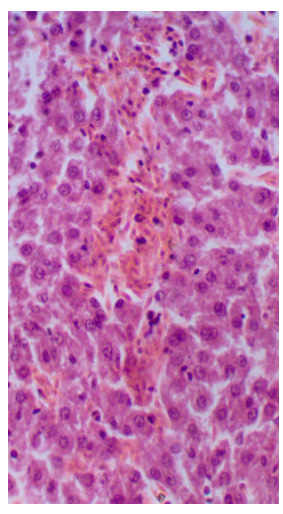

$\mathrm{b}$

Figure 15. Area of a chicken infected with $P$. aeruginosa and input the compound PKR-173 with the antibiotic Enrofloxacin. a - inflammatory cell infiltration close to a veins in a triad (x200); b hemorrhage in lobules parenchyma (x250). Hematoxylin-eosin 
After preventive input of Thiotriazolin with the classic antibiotic Enrofloxacin, a positive influence on the morphological state of liver was observed in $60 \%$ of chickens - recovery of typical outline of liver plates, absense of signs of fatty and hydropic dystrophy (fig. 16). Nevertheless, the rest of chickens had these indicators close to the level of controlled pathology (fig. 17).

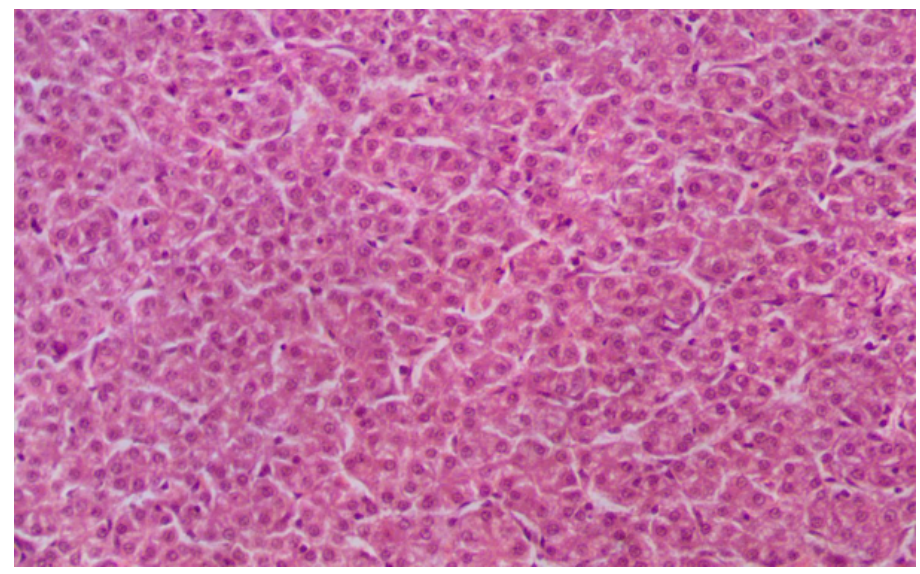

Figure 16. Area of a chicken infected with $P$. aeruginosa and input Thiotriazolin with the antibiotic Enrofloxacin. Normal outline with liver plates. Hematoxylin-eosin. x200

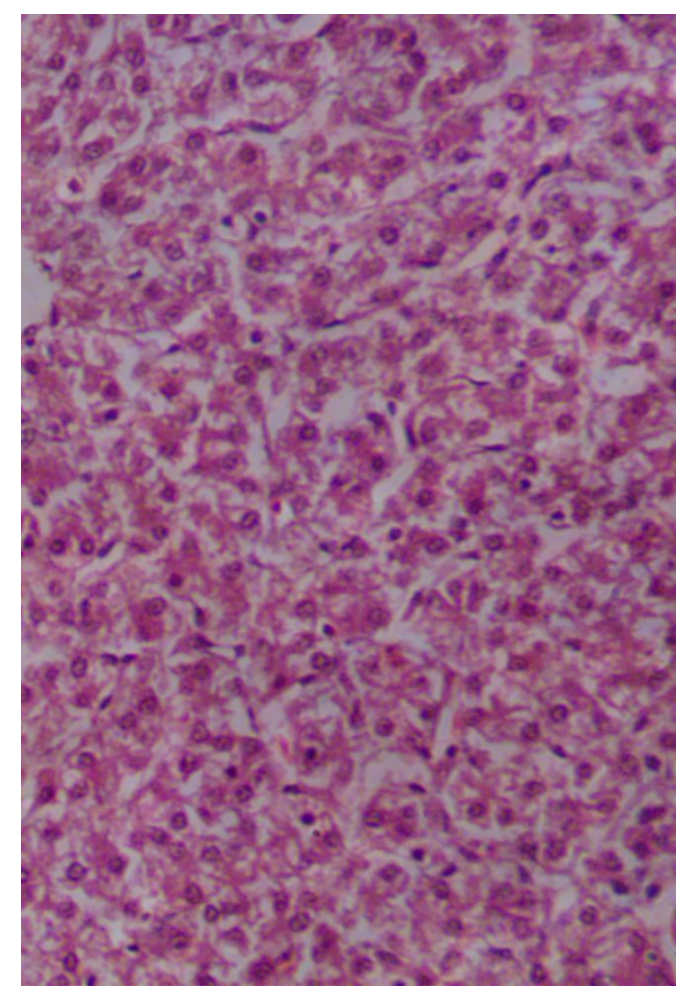

Figure 17. Area of a chicken infected with $P$. aeruginosa and input $t$ Thiotriazolin with the antibiotic Enrofloxacin. Blurred outlineof liver plates, vacuole dystrophy of hepatocytes. Hematoxylin-eosin. 
Hepatocytes necrosis and inflammatory perivascular round cell infiltration was absent in only $40 \%$ of chickens, and $60 \%$ of birds, even with lowered distinctiveness of these changes corresponding to the controlled pathology, were still quite visible (fig. 18).

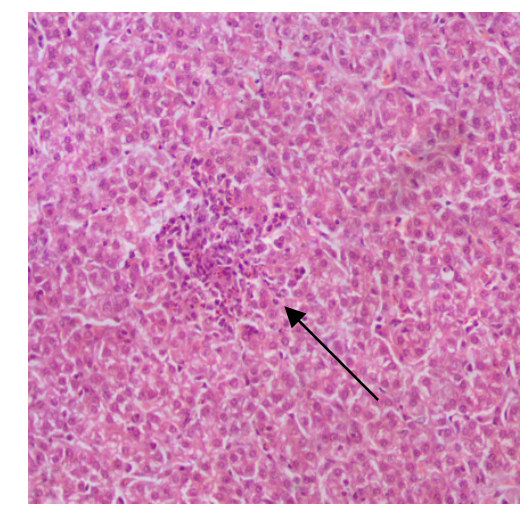

a

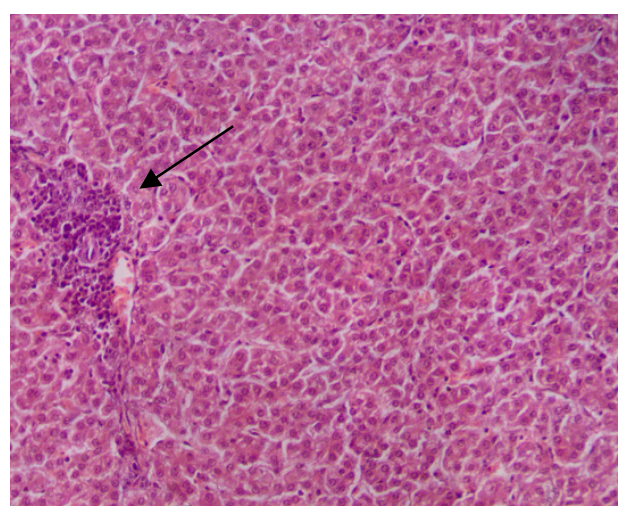

b

Figure 18. Area of a chicken infected with P. aeruginosa and input Thiotriazolin with the antibiotic Enrofloxacin. $\mathrm{a}$ - necrosis focus with blurred outlines, penetration of macrophages into a lobule; $\mathrm{b}-$ inflammatory round cell perivascular infiltration. Hematoxylin-eosin. x200

So, preventive input of the compound PKR-173 with reseachable antibiotic Saroflox, as well as with classic antibiotic Enrofloxacin and Thiotriazolin with antibiotic Enrofloxacin, to chickens infected with $P$. aeruginosa, prevents from chickens' livers developng stereotypical morphological changes characteristic of nonspecific reactive hepatitis which, obviously, is a result of overall toxic influence of endotoxins of a microorganism, facilitating the normalisation of organ histostructure, decrease of dystrophy and necrosis displays, inflammatory infiltration in vein sector of microcircular vessel. Visually the distinctiveness of hepatoprotective effect in all 3 groups is very close, even though it varies by some indicators. Thus, according to the set task, semiquantitative (graded) assessment of the corrective influence of the compound PKR-173 and Thiotriazolin with antibiotics on morphological state of chickens' liver parenchyma was conducted. The results of the graded assessment are shown in table 1 .

Analysis of quantitative characteristics of pathological process that developed in chicken's liver infected with $P$. aeruginosa, and the corrective influence of reseached methods showed that the compound PKR-173 with antibiotic Saroflox believably lowers displays of all signs of pathology compared to the controlled pathology.

Based on the distinctiveness of hepatoprotective effect the compound PKR-173 with antibiotic Saroflox believably analogical to the effect of this same compound with a classic antibiotic Enrofloxacin. 
Table 1. Semiquantitative assessment of corrective influence of the compound PKR-173 with different antibiotics on the 16-18 days old chickens' livers under conditions of infection by microorganisms $P$. aeruginosa (grades), M (min; max)

\begin{tabular}{|c|c|c|c|c|}
\hline \multirow[b]{2}{*}{ Experiment group } & \multicolumn{4}{|c|}{ indications, grades (average) } \\
\hline & $\begin{array}{c}\text { distinctiveness } \\
\text { of hepatocytes } \\
\text { dystrophy }\end{array}$ & $\begin{array}{l}\text { Necrosis changes } \\
\text { in hepatocytes }\end{array}$ & $\begin{array}{c}\text { breaches in plates' } \\
\text { outline }\end{array}$ & $\begin{array}{l}\text { inflammatory } \\
\text { infiltration, } \\
\text { connected to the } \\
\text { vessels }\end{array}$ \\
\hline Intact control & $0(0 ; 0)$ & $0(0 ; 0)$ & $0(0 ; 0)$ & $0.5(0 ; 2)$ \\
\hline P. aeruginosa (US) & $2.6(2 ; 3)^{*}$ & $1.6(1 ; 2)^{*}$ & $1.6(1 ; 2)^{*}$ & $2.2(2 ; 3)^{*}$ \\
\hline $\begin{array}{l}\text { PKR-173+ } \\
\text { antibiotic Saroflox } \\
\text { PKR-173+ } \\
\text { antibiotic }\end{array}$ & $0.8(0 ; 2)^{* *}$ & $0.4(0 ; 1)^{* *}$ & $0.4(0 ; 2)^{* *}$ & $0.12(0 ; 1)^{* *}$ \\
\hline $\begin{array}{l}\text { Enrofloxacin } \\
\text { Thiotriazolin } \quad+\end{array}$ & $0.12(0 ; 1)^{* *}$ & $0.12(0 ; 1)^{* *}$ & $0.12(0 ; 1)^{* *}$ & $2(2 ; 2)^{*} / \#$ \\
\hline Enrofloxacin & $0.8(0 ; 2)^{* *}$ & $0.6(0 ; 1)^{* *}$ & $0.6(0 ; 2)$ & $0.6(0 ; 1)^{* * / \psi}$ \\
\hline $\mathrm{p}$ & 0.0044 & 0.0069 & 0.0156 & 0.0013 \\
\hline
\end{tabular}

Notes: $\rho$ - level of statistical significance while comparing samples by means of Kruskal-Wallis criteria;

* - level of statistical significance while comparing research groups to US group by means of Mann-Whitney criteria;

** - level of statistical significance while comparing research groups to PS group by means of Mann-Whitney criteria;

\# - level of statistical significance while comparing research groups to PKR+Saroflox group by means of Mann-Whitney criteria;

$\psi$ - level of statistical significance while comparing research groups to PKR+Enrofloxacin group by means of Mann-Whitney criteria.

Based on absolute data the researchable compound with antibiotic Saroflox as for its hepatoprotective effect, specifically influence on anti-inflammatory processes in a liver, despite statistical reliance, Thiotriazolin with antibiotic Enrofloxacin preveils in comparison.

Prospects for further research are in more depth study of potassium 2-((4-amino-5(morpholinomethyl)-4H-1,2,4-triazol-3-yl)thio)acetate on the ability of display hepatoprotective effect on various models of hepatitis. 


\section{REFERENCES}

1. World Health Organization. (2017). Global hepatitis report 2017. World Health Organization. $83 p$.

2. Rud, A.M., Kaplaushenko, A.G., Pruglo, E.S., Frolova, Y.S. (2017). Hepatoprotective activity of 1,2,4-triazole-3-thione derivatives, which contains on $\mathrm{C}_{5}$-atomic carbon hydroxy (phenyl) methyl dependent. Farmatsevtychnyi Zhurnal, (5-6), 55-63.

3. Shcherbyna, R. O., Samura, T. O., Kyrychko, B. P., Zvenihorodska, T. V., Hyrenko, I. V. (2017). The research of ammonium 2-((4-amino-5-(morpholinomethyl)-4H-1, 2, 4-triazole-3-yl) thio) acetate (PKR-177) influence on biochemical indices in rats blood under hepatitis initiated by tetrachloride methane. Zaporožskij Medicinskij Žurnal, 19(6), 819-822.

4. Al-Soud, Y. A., Al-Dweri, M. N., Al-Masoudi, N. A. (2004). Synthesis, antitumor and antiviral properties of some 1, 2, 4-triazole derivatives. Il Farmaco, 59 (10), 775-783.

5. Awad, L. F., El Sayed, H. (1998). Synthesis and conformational analysis of seco C-nucleosides and their diseco double-headed analogues of the 1, 2, 4-triazole, 1, 2, 4-triazolo [3, 4-b] 1, 3, 4thiadiazole. Carbohydrate Research, 312(1-2), 9-22.

6. Colanceska-Ragenovic, K., Dimova, V., Kakurinov, V., Molnar, D., Buzarovska, A. (2001). Synthesis, antibacterial and antifungal activity of 4-substituted-5-aryl-1, 2, 4-triazoles. Molecules, 6(10), 815-824.

7. Demirbas, N., Karaoglu, S. A., Demirbas, A., Sancak, K. (2004). Synthesis and antimicrobial activities of some new 1-(5-phenylamino-[1, 3, 4] thiadiazol-2-yl) methyl-5-oxo-[1, 2, 4] triazole and 1-(4-phenyl-5-thioxo-[1, 2, 4] triazol-3-yl) methyl-5-oxo-[1, 2, 4] triazole derivatives. European Journal of Medicinal Chemistry, 39(9), 793-804.

8. Foroumadi, A., Mirzaei, M., Shafiee, A. (2001). Antituberculosis agents II. Evaluation of in vitro antituberculosis activity and cytotoxicity of some 2-(1-methyl-5-nitro-2-imidazolyl)-1,3,4thiadiazole derivatives. Il Farmaco, 56(8), 621-623.

9. Labanauskas, L., Udrenaite, E., Gaidelis, P., Brukštus, A. (2004). Synthesis of 5-(2-, 3-and 4methoxyphenyl)-4H-1,2,4-triazole-3-thiol derivatives exhibiting anti-inflammatory activity. Il Farmaco, 59(4), 255-259.

10. El-Azzouny, A., Maklad, Y., Bartsch, H., Zaghary, W., Ibrahim, W., Mohamed, M. (2003). Synthesis and pharmacological evaluation of fenamate analogues: 1, 3, 4-oxadiazol-2-ones and 1, 3, 4-oxadiazole-2-thiones. Scientia Pharmaceutica, 71(4), 331-356.

11. Grover, G., Kini, S. G. (2003). Synthesis and evaluation of new 1,3,4-oxadiazoles and 1,3,4oxadiazole-2-thione derivatives of nalidixlc acid as potential antibacterial and antifungal agents. Indian Journal of Heterocyclic Chemistry, 12(3), 289-290.

12. Amtul, Z., Rasheed, M., Choudhary, M. I., Rosanna, S., Khan, K. M. (2004). Kinetics of novel competitive inhibitors of urease enzymes by a focused library of oxadiazoles/thiadiazoles and triazoles. Biochemical and Biophysical Research Communications, 319(3), 1053-1063.

13. Rai, K. L., Linganna, N. (2000). Synthesis and evaluation of antimitotic activity of alkylated 2amino-1,3,4-oxadiazole derivatives. Il Farmaco, 55(5), 389-392. 
14. Khan, M. T. H., Choudhary, M. I., Khan, K. M., Rani, M. (2005). Structure-activity relationships of tyrosinase inhibitory combinatorial library of 2,5-disubstituted-1,3,4-oxadiazole analogues. Bioorganic \& Medicinal Chemistry, 13(10), 3385-3395.

15. Karabasanagouda, T., Adhikari, A. V., Shetty, N. S. (2007). Synthesis and antimicrobial activities of some novel 1,2,4-triazolo [3, 4-b]-1,3,4-thiadiazoles and 1,2,4-triazolo [3,4-b]-1,3,4thiadiazines carrying thioalkyl and sulphonyl phenoxy moieties. European Journal of Medicinal chemistry, 42(4), 521-529.

16. Mathew, V., Keshavayya, J., Vaidya, V. P., Giles, D. (2007). Studies on synthesis and pharmacological activities of 3,6-disubstituted-1,2,4-triazolo [3,4-b]-1,3,4-thiadiazoles and their dihydro analogues. European Journal of Medicinal Chemistry, 42(6), 823-840.

17. Zhang Z.Y, Sun X. W. (1998). S-Triazolo[3,4-b]-1,3,4-thiadiazole derivatives. Heterocycles, 48, 561- 584 .

18. Bushueva, I., Parchenko, V., Shcherbyna, R., Safonov, A., Kaplaushenko, A., Gutyj, B., Hariv, I. (2017). Tryfuzol-New Original Veterinary Drug. Ankara Üniversitesi Eczacilık Fakültesi Dergisi, $41(1), 42-49$.

19. Shcherbyna, R.O., Vashchyk, Y.V. (2018). Histological study of potassium 2-((4-amino-5(morpholinomethyl)-4H-1, 2, 4-triazole-3-yl)thio)acetate (PKR-173) corrective influence on the chickens liver state in the condition of tetracycline hepatitis. Zaporožskij Medicinskij Žurnal, 3 , 404-412.

20. Fotina T.I., Vashchyk Ye.V., Shcherbyna R.O. (2018). The problem of pseudomonas aeruginosa antibiotic- resistance and search of effective means of fighting. Veterinary Biotechnology, 32, 577-584.

21. Vashhyk Ye.V. (2009). To the study of the mechanisms of development of the infectious process in the pseudomonosis of the bird. Zb. nauk. pracj. Kharkivsjkoji DZVA, ser. Veterynarni Nauky, $20,220-224$.

22. Skrypka M.V. (1999). Pseudomonosis of poultry in Ukraine and biological properties of the pathogen, PhD Thesis, Kharkiv, $130 \mathrm{p}$.

23. Shcherbyna, R. O. (2017). Synthesis, physical and chemical properties of 2-((4-R-3(morfolinomethylen)-4H-1, 2, 4-triazole-5-yl) thio) acetic acid salts. Current Issues in Pharmacy and Medicine: Science and Practice, 10 (1), 4-8.

24. Bovkun G.F., Borisenkova A. N. (1995). Biological properties of Pseudomonas aeruginosa and its role in pathology of poultry. Veterinariya, 32, 30-33.

25. Semyna, S. A., Sydorenko, S. V., Rezvan, S. P. (2004) Determination of the sensitivity of microorganisms to antibiotics. Methodical instructions 4.2.1890-04. Clinical Microbiology and Antimicrobial Chemotherapy, 6 (4), 306-359.

26. Ashmarin I. P., Vorob'ev L. A. (1962). Statistical methods in microbiological research. L.: Medicine, $178 \mathrm{p}$. 
27. Shcherbyna, R., Vashchyk, Y. (2019). The research of 1,2,4-triazole derivatives hepatoprotective activity under tetracycline and infectious hepatitis. Ankara Üniversitesi Eczacıllk Fakültesi Dergisi, 43(2), 135-146.

28. Tiotriazolin ${ }^{\circledR}$ tablets - instructions, analogues, composition, indications, reviews. Arterium Corporation. Reference http://compendium.com.ua/info/7043/tiotriazolin-sup-sup-. Published 2019. Accessed July 20, 2019.

29. Merkulov GA. (1969). Course of pathological histology. Medicine, Moscow.343 p.

30. Sokolovskiy V.V. (1971). Histochemical studies in toxicology. Medicine, St. Petersburg. 175p.

31. Khalafyan, A. A. (2007). STATISTICA 6. Statistical analysis of data. M.: Binom-Press,512p.

32. Lapach, S. N., Chubenko, A. V., Babich, P. N. (2000). Statistical methods in biomedical research using Excel. K.: Morion, 320 p.

33. Rebrova, O. J. (2010). Statistical analysis of medical data: application of the STATISTICA software package. Moskva, Media Sfera, 312 .

34. Khamitova, L. Y. (2015). Comparative analysis of morphofunctional indicators of the liver of doves and broilers in the critical periods of ontogenesis. Dr. biol. sci. diss., Omsk, 205p.

35. Kelberg, N. A., Sadovnikov, N. V. (2010). The role of the liver in the metabolism of birds. The morphological changes in the poultry liver while using antihomotoxic therapy. Agrarian Bulletin of the Urals, 1(67), 60-63. 